\title{
DISTRIBUTION OF HEAVY METALS IN VARIOUS COMPARTMENTS OF THE CONSTRUCTED WETLAND SYSTEM IN PRZYWIDZ
}

\author{
Hanna Obarska-Pempkowiak \\ Technical University of Gdańsk Poland \\ Katarzyna Klimkowska \\ Warsaw Agricultural University, Poland
}

\begin{abstract}
In the last decade constructed wetlands have become a very popular technology for removal of contaminants from domestic sewage. They are also assesed from the point of view of their capacity for removal of toxic heavy metals and organic substances resistant to degradation.

Constructed wetland in Przywidz localized about $60 \mathrm{~km}$ from Gdańsk is a pilot wastewater treatment plant (WWTP) designed for $150 \mathrm{PE}$ (person equivalent). The system consists of two sections: vegetated submerged bed (VSB) with horizontal flow of sewage and a cascade filter situated on a slope of a hill. Domestic sewage after a conventional pretreatment (consists of an Imhoff tank and a trickling filter) is pumped to the VSB filter located on slope of the hill. Total area of constructed wetland is about $870 \mathrm{~m}^{2}$.

In the period 1995-98 the measurments of several heavy metals $(\mathrm{Cd}, \mathrm{Cu}, \mathrm{Pb})$ were carried out. These measurments were carried out in inflowing and outflowing sewage and as well in samples collected from each section of constructed wetland system. In particular analysis of sediment collected in ditches of the cascade filter, filling material of the dykes, VSB filter and plants were carried out.

It was found out that content of heavy metals in suspended soil decreased along the course of treatment, starting from VSB filter, through the first ditch to the last ditch. Measurable concentration of dissolved heavy metals were found in sewage collected from several subsequent ditches. The main mechanism of removal on particular matter in subsequent ditches was sorption.
\end{abstract}

\section{Keytwords}

heavy metals, wetland, retention, accumulation, reed.

\section{Introduction}

In the rural areas in Poland the farm buildings are usually scatered at long distances. Therefore applying an integral sewer system and treatment of sewage is economically unjustified. Only $3.8 \%$ of villages are connected to the sewer systems and just a half of these $3.8 \%$ have their sewage treated in the wastewater treatment plants. 
The local treatment of sewage usually takes place in septic tanks that provide only mechanical treatment. Often these tanks are leaking and the outflowing sewage, in many cases, is not suffciently purified.

The quality standards for sewage discharged to the surface waters are severe in Poland, also in the case of small volumes of sewage. This situation asks for research and application of new technologies and solutions, sometimes not fully established. One of the new methods applied for sewage treatment are the wetland systems or constructed wetland systems.

Constructed wetland systems have become a very popular technology for removal of contaminants from domestic sewage. However, the new application of these systems is their utilization for removal of heavy metals. The potential of wetland systems for removal of heavy metals is the result of the lack of biological barrier in the macrophyte plants, due to which the passive adsorption of heavy metal ions occurs. Retaining of heavy metals in the wetland system may be also the result of binding by microorganisms. There are two mechanisms of heavy metals retention by microorganisms: formation of complex extracellular compounds composed of heavy metals and substances released by the cells and biosorption of the metal ions on the cells' surfaces.

Ozimek and Renman (1996) discovered a simple relationship between the distribution of heavy metals in the wetland environment and their content in the macrophyte plants.

The amount of heavy metals retained as well as the retention rate depend on the environmental factors such as the content of organic and mineral suspended solids in water and bottom sediments. Most of heavy metals are dissolved in water for just a short period of time since they are quickly adsorbed by the mineral and organic fraction of the bottom sediments and by the detritus suspended in the water.

According to Vymazal et al. (1998) the heavy metals precipitate in the form of carbonates and sulphides, produced in the redox reactions.

This paper is aimed at evaluation of distribution of three heavy metal ions: $\mathrm{Pb}, \mathrm{Cu}$ and $\mathrm{Cd}$ in the wetland ecosystem inhabitated with reed. Metals are supplied with domestic sewage from the Przywidz village near Gdańsk.

\section{The wetland system in Przywidz}

The wetland system in Przywidz (the Pommeranian region), inhabitated with reed, was constructed as a pilot-scale one, for treating domestic sewage. Prior to inflowing to the wetland system, the sewage are treated in a conventional wastewater treament plant consisting of an Imhoff tank and trickling biofilter. The amount of inflowing sewage equals to $22.5 \mathrm{~m}^{3} \mathrm{~d}^{-1}$, which corresponds to $150 \mathrm{PE}$ (person equivalent). The wetland system consists of two parts. The first one is a vegetated submerged bed (VSB) with horizontal flow (of the area of $150 \mathrm{~m}^{2}$ ). The second part is a cascade filter (KFTG), planted with reed, of the area of 720 $\mathrm{m}^{2}$. The cascade filter itself consists of two parts: upper cascade (KFTG-1) and lower cascade (KFTG-2). Each cascade is composed of three internal dams wich are separated by four ditches. The length of each dam is $30 \mathrm{~m}$. The bottom of each subsequent ditch is placed $25 \mathrm{~cm}$ below the bottom of the preceding one.

Gravitational flow of sewage is secured by the filter being situated on slope of a hill. After passing through the VSB filter, the sewage is directed to the first ditch of the upper cascade, where it is aerated. While the ditch is filling, the sewage percolates through the first dam to the lower ditch, again percolates through the second dam and so on. Sewage from subsequent parts of the constructed wetland was drained with a drainage pipe and collected in an inspection chamber. The so obtained outflow was directed to the next part of the wetland. Schematic illustration of the construsted wetland system in Przywidz is given in the Fig. 1. 


\section{Materials and methods}

In the period 1996-98 the measurments of efficiency of removal of heavy metals $(\mathrm{Cd}, \mathrm{Pb}$ and $\mathrm{Cu}$ ) from sewage were performed at the following sampling points:

1 - the inflow to the VSB (the inflow to the wetland system),

11 - the first ditch of the upper cascade KFTG-1 (effluent from the VSB),

14 - the last (fourth) ditch of the upper cascade KFTG-1 (effluent from the KFTG-1),

24 - the last (fourth) ditch of the lower cascade KFTG-2 (the effluent from the wetland system).

Location of the sampling points is presented in the Fig. 1. In order to investigate the distribution of the analysed heavy metals in each of the component parts of the wetland system, the measurments of the content of these elements in the bottom sediments stored in the ditches, as well as in the filtering material and in reed were performed.

The samples of the bottom sediments were taken in the following points:

11 - the first ditch of the upper cascade (KFTG-1),

14 - the last (fourth) ditch of the upper cascade (KFTG-1),

24 - the last (fourth) ditch of the lower cascade (KFTG-2).

The samples of the filtering material were taken at the VSB filter:

$1 \mathrm{~d}$ - the inffluent to the VSB,

10 - the effluent from the VSB, as well as from the following locations on the dyke of the KFTG filter:

13 - from the submerged part (under the water table) of the third dyke of the KFTG-1,

23 - from the submerged part of the third dyke of the KFTG-2.

The samples of sewage were collected in spring, summer, autumn. The plants material were collected for analyses from the VSB, KFTG-1 and KFTG-2 filters during spring, summer and autumn. The samples of bottom sediment and filtering material were collected at the begining and at the end of investigation period (1995-1998).

The contents of heavy metal ions were measured both in the solution and in the suspended solids. $1 \mathrm{dm}^{3}$ of the sewage was filtered on the $0.45 \mu \mathrm{m}$ membrane. Then the filtrate was evaporated to dryness and dissolved in the $0.1 \mathrm{~mol} \mathrm{dm}^{-3} \mathrm{HNO}_{3}$. The filters were dried and wet digested $\left(\mathrm{HCl}: \mathrm{HNO}_{3}=3: 1\right)$. The acids were evaporated and the residue dissolved in $0.1 \mathrm{~mol} \mathrm{dm}{ }^{-3} \mathrm{HNO}_{3}$ (Obarska-Pempkowiak \& Klimkowska, 1999).

In order to determine the total content of the heavy metals in the plants, the samples of the mass of $1.000 \mathrm{~g}$ were collected and mineralised with $5 \mathrm{~cm}^{3}$ of aqua regia, during 2 hours in the temperature of $80^{\circ} \mathrm{C}$. The mixture was then centrifuged and evaporated to dryness. The residue was dissolved in $0,1 \mathrm{~mol} \mathrm{dm}^{-3} \mathrm{HNO}_{3}$ and the content of heavy metals was determined.

Sequential extraction of heavy metals was carried out according to a procedure described earlier (Obarska-Pempkowiak \& Klimkowska, 1999; Forstner \& Witmann, 1981). In short: $1.000 \mathrm{~g}$ subsamples of dried $\left(105^{\circ} \mathrm{C}, 4\right.$ hours) sediment or the dykes construction material were shaked for 16 hours with $10 \mathrm{~cm}^{3}$ of $0.1 \mathrm{~mol} \mathrm{dm}^{-3} \mathrm{CH}_{3} \mathrm{COOH}$. The solution was separated by centrifugation. Extract was used for heavy metals determination (labile fraction of heavy metals), while solid residue was shaked with $10 \mathrm{~cm}^{3}$ of $€ .5 \mathrm{~mol} / \mathrm{dm}^{3} \mathrm{NH}_{2} \mathrm{OH} \cdot \mathrm{HCl}(\mathrm{pHe}=2.0)$, the solution was again separated by centrifugation, extract was used for heavy metals determination (hydroxide fraction of heavy metals). This was followed by digestion of solid residue with $8.8 \mathrm{~mol} \mathrm{dm}^{-3} \mathrm{H}_{2} \mathrm{O}_{2}$ and extraction with $1.0 \mathrm{~mol} \mathrm{dm}^{-3} \mathrm{CH}_{3} \mathrm{COONH}_{4}, \mathrm{pH}=2.0$ (organic fraction of heavy metals). The last stage of the procedure was digestion of solid 
residue with hydrofluoric acid, evaporation to dryness. dissolution in $0.1 \mathrm{~mol} \mathrm{dm}{ }^{-3} \mathrm{HNO}_{3}$ and determination of heavy metals in the so obtained solution (residual fraction of heavy metals).

The amount of sewage was evaluated indirectly, knowing the time of operation of the pump and its average capacity $\left(Q_{s}=Q_{p s} t\right)$. The pump was operated automatically, depending on the water level in the well. In order to measure the time of operation of the pump, the counting device (type NOD-LGS) was installed on the switchboard. The average capacity of the pump $\left(\mathrm{Q}_{\mathrm{ps}}\right)$ was estimated knowing the volume of the control layer in the wet well of the pumping station $\left(\mathrm{V}_{\mathrm{s}}\right)$ and the time of draining $(\mathrm{t})$

$$
\mathrm{Q}_{\mathrm{ps}} \mathrm{e}=\mathrm{V}_{\mathrm{s}} \mathrm{t}^{-1}
$$

\section{Results}

The measured content of cadmium, copper and lead in various parts of reed collected from the VSB filter and from the fourth ditch of the lower cascade (KFTG-2) are presented in Tables 1 and 2. The "total" contents in the table refer to the content of metals in samples collected in spring. summer and autumn. The highest accumulation of heavy metals was found in the rhizomes. The highest amounts of $\mathrm{Pb}$ and $\mathrm{Cu}$ in the rhizomes were present in summer while the amounts of $\mathrm{Cd}$ were highest in spring. The accumulation of these elements in subsequent parts of the system, as given in Table 2.

The yearly average concentration of the suspended solids in sewage after the subsequent compartments of the wetland system and the daily load of the analysed metals are presented in Table 3. The obtained results indicate significant role of the first part of the wetland system the VSB filter in elimination of heavy metals $(69.6 \% \mathrm{Cd}, 69.2 \% \mathrm{Cu}$ and $64.3 \% \mathrm{~Pb})$. The average efficiency of elimination of the analysed elements in the whole wetland system was equal to: $92.3 \% \mathrm{Cd}, 89.4 \% \mathrm{Cu}$ and $87.8 \% \mathrm{~Pb}$.

TABLE 1

The contents of cadmium, copper and lead in different parts of reed (VSB)

\begin{tabular}{|lllcc|}
\hline Season & Part of reed & \multicolumn{3}{c|}{ Content $\left(\mu \mathrm{g} \mathrm{DM}^{-1}\right)$} \\
\cline { 3 - 5 } & & $\mathbf{C d}$ & $\mathbf{C u}$ & $\mathbf{P b}$ \\
\hline \multirow{3}{*}{ Spring } & stalk & 0.062 & 0.75 & 0.82 \\
& leaves & 0.183 & 2.48 & 2.12 \\
& roots & 0.194 & 0.39 & 1.49 \\
& rhizomes & 0.980 & 12.30 & 8.70 \\
\hline \multirow{3}{*}{ Summer } & stalk & 0.060 & 1.42 & 0.92 \\
& leaves & 0.213 & 3.91 & 2.61 \\
& roots & 0.092 & 1.20 & 0.74 \\
& rhizomes & 0.800 & 19.40 & 10.60 \\
\hline \multirow{3}{*}{ Autumn } & stalk & 0.054 & 0.65 & 0.61 \\
& leaves & 0.161 & 3.12 & 3.14 \\
& roots & 0.074 & 1.94 & 0.68 \\
& rhizomes & 0.690 & 16.70 & 6.40 \\
\hline
\end{tabular}


The contents of cadmium, copper and lead in different parts of reed (KFTG - 24)

\begin{tabular}{|lllcl|}
\hline Season & Part of treed & \multicolumn{3}{c|}{ Content $\left(\mu \mathrm{g} \mathrm{g} \mathrm{DM}{ }^{-1}\right)$} \\
\cline { 3 - 5 } & & $\mathbf{C d}$ & $\mathbf{C u}$ & $\mathbf{P b}$ \\
\hline \multirow{3}{*}{ Spring } & stalk & 0.045 & 0.79 & 0.41 \\
& leaves & 0.161 & 2.46 & 1.12 \\
& roots & 0.170 & 0.58 & 0.86 \\
& rhizomes & 0.410 & 7.20 & 4.30 \\
\hline \multirow{3}{*}{ Summer } & stalk & 0.040 & 1.26 & 0.39 \\
& leaves & 0.145 & 3.13 & 1.13 \\
& roots & 0.068 & 1.35 & 0.36 \\
& rhizomes & 0.610 & 10.20 & 5.40 \\
\hline \multirow{3}{*}{ Autumn } & stalk & 0.037 & 0.41 & 0.32 \\
& leaves & 0.124 & 2.91 & 1.38 \\
& roots & 0.058 & 1.32 & 0.29 \\
& rhizomes & 0.720 & 6.50 & 3.90 \\
\hline
\end{tabular}

TABLEt3

Average concentration of total suspended solids and loads of $\mathrm{Cd}, \mathrm{Cu}$ and $\mathrm{Pb}$ in sewage after subsequent stages of treatment in Przywidz

\begin{tabular}{|l|c|c|c|c|}
\hline \multicolumn{1}{|c|}{ Measuring point } & $\begin{array}{c}\text { Suspended } \\
\text { solids } \mathrm{mg} \mathrm{l}^{-1}\end{array}$ & $\begin{array}{c}\mathrm{Cd} \\
\mathrm{mg} \mathrm{d}^{-1}\end{array}$ & $\begin{array}{c}\mathrm{Cu} \\
\mathrm{mg} \mathrm{d}^{-1}\end{array}$ & $\begin{array}{c}\mathrm{Pb} \\
\mathrm{mg} \mathrm{d}^{-1}\end{array}$ \\
\hline Inflow to VSB & 201.4 & 67.1 & 408.7 & 353.3 \\
Outflow from VSB & 114.5 & 33.4 & 171.0 & 164.0 \\
Outflow from KFTG-1 & 56.2 & 12.6 & 105.7 & 77.5 \\
Outflow from KFTG-2 & 38.1 & 8.4 & 86.2 & 54.8 \\
\hline
\end{tabular}

TABLEt4

Balance of heavy metals in constructed wetland system in Przywidz, in $\mathrm{g} \mathrm{a}^{-1}$

\begin{tabular}{|lccc|}
\hline Metals & Influent & Reed & Effluent \\
$\mathrm{Cd}$ & 26.56 & 0.12 & 3.28 \\
$\mathrm{Cu}$ & 148.92 & 2.15 & 31.39 \\
$\mathrm{~Pb}$ & 128.48 & 1.41 & 20.07 \\
\hline
\end{tabular}


The results allowed for counting a simplified balance for the analysed heavy metals: Cd, $\mathrm{Cu}$ and $\mathrm{Pb}$ in the wetland ecosystem. The results are given in Table 4 . They confirm that substantial part of the analysed elements is retained in the filtering materials of the dykes and in the bottom sediments of the ditches. Accumulation in the reed biomass was much smaller and equaled to $14.8 \% \mathrm{Cd}, 22.1 \% \mathrm{Cu}$ and $13.8 \% \mathrm{~Pb}$.

The results obtained from the sequential extraction of the filtering material of the dykes and for the bottom sediments are given in Tables 5 and 6 . The content of copper showed the biggest variations, the content of cadmium - smaller, while the content of lead changed slightly. Both the smallest amounts and the smallest variations of analysed elements were found in the filtering materials of the dykes. The biggest variations were noted in the bottom sediments.

The content of heavy metals decreased in the subsequent compartments of the wetland system. The highest amounts of all three metals were retained in the first stage of the system, that is in the VSB filter, while in the next stages (KFTG-1 and KFTG-2) the elimination of analysed elements was much smaller. Both the contents of $\mathrm{Pb}$ and $\mathrm{Cu}$ decreased slightly in the filtering material of the dykes, while there was almost no change in the contents of analysed elements in the ditches.

TABLEt5

Sequence extraction in the filtering medium of the dykes in the constructed wetland system in

Przywidz

\begin{tabular}{|c|c|c|c|c|c|c|c|c|c|}
\hline \multirow[t]{2}{*}{ Fraction } & \multicolumn{3}{|c|}{ Cd } & \multicolumn{3}{|c|}{$\mathbf{C u}$} & \multicolumn{3}{|c|}{$\mathbf{P b}$} \\
\hline & $\begin{array}{l}11 \\
\text { KFTG1 }\end{array}$ & $\begin{array}{l}13 \\
\text { KFTG } 1\end{array}$ & $\begin{array}{l}23 \\
\text { KFTG2 }\end{array}$ & $\begin{array}{l}11 \\
\text { KFTG1 }\end{array}$ & $\begin{array}{l}13 \\
\text { KFTG } 1\end{array}$ & $\begin{array}{l}23 \\
\text { KFTG2 }\end{array}$ & $\begin{array}{l}11 \\
\text { KFTG1 }\end{array}$ & $\begin{array}{l}13 \\
\text { KFTG } 1\end{array}$ & $\begin{array}{l}23 \\
\text { KFTG2 }\end{array}$ \\
\hline $\mathrm{L}^{*}$ & $\frac{0.23}{0.31}$ & $\frac{0.17}{0.16}$ & $\frac{0.06}{0.09}$ & $\frac{0.31}{1.32}$ & $\frac{0.25}{0.34}$ & $\frac{0.24}{0.23}$ & $\frac{1.43}{7.20}$ & $\frac{1.39}{2.80}$ & $\frac{1.39}{2.50}$ \\
\hline $\mathrm{Ht}$ & $\frac{0.03}{0.04}$ & $\underline{0.04}$ & $\frac{0.08}{0.04}$ & $\underline{0.17}$ & $\frac{0.36}{0.24}$ & $\frac{0.63}{0.12}$ & $\frac{1.13}{1.30}$ & $\frac{0.86}{0.70}$ & $\frac{0.55}{0.40}$ \\
\hline $\mathrm{O}^{\text {sar }}$ & $\frac{0.04}{0.04}$ & $\frac{0.02}{0.02}$ & $\frac{0.01}{0.02}$ & $\frac{9.36}{12.59}$ & $\frac{4.10}{5.34}$ & $\frac{3.00}{5.25}$ & $\frac{32.85}{30.90}$ & $\frac{19.77}{20.70}$ & $\frac{20.09}{24.30}$ \\
\hline $\mathrm{R}^{\mathrm{Im}}$ & $\frac{0.01}{0.04}$ & $\frac{0.01}{0.02}$ & $\frac{0.01}{0.02}$ & $\frac{22.91}{15.31}$ & $\frac{14.37}{13.20}$ & $\frac{13.50}{13.83}$ & $\frac{23.72}{23.10}$ & $\frac{16.67}{17.40}$ & $\frac{18.32}{17.00}$ \\
\hline$\Sigma$ & $\frac{0.30}{0.43}$ & $\frac{0.24}{0.24}$ & $\frac{0.16}{0.17}$ & $\frac{26.75}{29.36}$ & $\frac{19.08}{18.92}$ & $\frac{17.43}{19.43}$ & $\frac{59.13}{52.30}$ & $\frac{38.69}{41.60}$ & $\frac{40.35}{44.20}$ \\
\hline
\end{tabular}


TABLEt6

Sequence extraction in the bottom sedimens of the ditches in the constructed wetland system in Przywidz

\begin{tabular}{|c|c|c|c|c|c|c|c|c|c|}
\hline \multirow[t]{2}{*}{ Fraction } & \multicolumn{3}{|c|}{ Cd } & \multicolumn{3}{|c|}{$\mathrm{Cu}$} & \multicolumn{3}{|c|}{$\mathbf{P b}$} \\
\hline & $\begin{array}{l}11 \\
\text { KFTG1 }\end{array}$ & $\begin{array}{l}14 \\
\text { KFTG } 1\end{array}$ & $\begin{array}{l}24 \\
\text { KFTG2 }\end{array}$ & $\begin{array}{l}11 \\
\text { KFTG1 }\end{array}$ & $\begin{array}{l}14 \\
\text { KFTG } 1\end{array}$ & \begin{tabular}{|l}
24 \\
KFTG2
\end{tabular} & $\begin{array}{l}11 \\
\text { KFTG } 1\end{array}$ & $\begin{array}{l}14 \\
\text { KFTG } 1\end{array}$ & $\begin{array}{l}24 \\
\text { KFTG2 }\end{array}$ \\
\hline $\mathrm{L}^{*}$ & $\frac{0.49}{1.20}$ & $\underline{0.15}$ & $\frac{0.11}{0.20}$ & $\frac{0.40}{2.50}$ & $\frac{0.19}{0.40}$ & $\frac{0.18}{0.40}$ & $\frac{2.05}{9.70}$ & $\frac{0.69}{2.70}$ & $\frac{2.61}{2.30}$ \\
\hline $\mathrm{H}^{\mathrm{nt}}$ & $\frac{0.27}{0.40}$ & $\frac{0.21}{0.20}$ & $\frac{0.21}{0.10}$ & $\frac{0.71}{0.20}$ & $\frac{0.82}{0.20}$ & $\frac{0.10}{0.20}$ & $\frac{1.07}{1.60}$ & $\frac{1.59}{0.90}$ & $\frac{0.88}{0.70}$ \\
\hline $\mathrm{O}^{* * *}$ & $\frac{0.05}{0.20}$ & $\frac{0.03}{0.10}$ & $\frac{0.02}{0.30}$ & $\frac{11.48}{16.30}$ & $\frac{6.84}{4.40}$ & $\frac{5.27}{4.70}$ & $\frac{9.81}{30.80}$ & $\frac{6.97}{20.10}$ & $2 \frac{7.89}{1.60}$ \\
\hline $\mathrm{R}^{\mathrm{m} m}$ & $\frac{3.73}{2.60}$ & $\frac{0.03}{2.10}$ & $\frac{0.10}{2.00}$ & $\frac{10.40}{13.90}$ & $\frac{6.17}{11.70}$ & $\frac{6.90}{12.90}$ & $\frac{16.15}{22.10}$ & $\frac{15.14}{17.30}$ & $\frac{14.63}{16.70}$ \\
\hline$\Sigma$ & $\frac{4.54}{4.60}$ & $\frac{0.42}{2.70}$ & $\frac{0.44}{2.60}$ & $\frac{20.60}{32.90}$ & $\frac{14.10}{16.90}$ & $\frac{12.00}{18.40}$ & $\frac{28.04}{64.00}$ & $\frac{24.66}{41.00}$ & $\frac{24.92}{41.30}$ \\
\hline
\end{tabular}

$\mathrm{L}^{*}$ - labile, $\mathrm{H}^{\prime \prime}$ - hydroxide, $\mathrm{O}^{* * *}$ - organic, $\mathrm{R}^{* *}$ - residual

The amount of elements retained in the ditches and in the filtering material of the dykes increased in 1998 in comparison to 1996. The highest increase of the content of analysed metals was noted in the ditches. The highest retention took place in the first ditch of the KFTG-1 filter. Accumulation of $\mathrm{Cu}$ and $\mathrm{Pb}$ in this ditch increased 1.6 and 2.3 times, respectively. Accumulation of $\mathrm{Cd}$ did not increase in the first ditch of the KFTG-1 filter. However in the last ditches of both upper and lower cascade the amount of $\mathrm{Cd}$ increased 6 times. while the amounts of $\mathrm{Pb}$ and $\mathrm{Cu}$ in these ditches increased only 2 times and $1.2-1.5$ times, respectively.

The analysis of the fractions obtained in the sequential extraction indicated the highest accumulation of $\mathrm{Cu}$ in the organic fraction (both in 1996 and in 1998). Almost $50 \%$ of the total amount of $\mathrm{Cu}$ gathered in the bottom sediments was accumulated in the organic fraction. The share of $\mathrm{Cu}$ in the organic fraction of the filtering material of the dykes was highest for the first dyke of the KFTG-1 (35.0\%) and for the other dykes it was smaller $-21.5 \%$ for the third and $17.2 \%$ for the last dyke of the KFTG-2. In the case of the filtering material of the dykes $\mathrm{Cu}$ was accumulated mostly in the residual fraction. The proportion of $\mathrm{Cu}$ equaled to $85.6 \%, 75.3 \%$ and $77.5 \%$ in the first and the last dykes of the KFTG- 1 and in the last dyke of KFTG2, respectively. In 1998 the amount of $\mathrm{Cu}$ in the organic fraction increased and in the subsequent samples it corresponded to: $42.9 \%$ (for VSB), $28.2 \%$ (KFTG-13) and $27.0 \%$ (KFTG-23).

Lead was accumulated mainly in the stable fractions (organic and residual) of the bottom sediments, in the suspended solids of the treated sewage and in the filtring material of the dykes. In 1998 the content of $\mathrm{Pb}$ in organic fraction of the bottom sediments increased if compared to 1996. For instance in the first ditch of the KFTG-1 accumulation of $\mathrm{Pb}$ increased from 35.0 to $48.0 \%$, in the fourth ditch of KFTG-1 from 28.3 to $48.0 \%$ and in the last ditch of the KFTG-2 - from 31.7 to $52.3 \%$. There was no increase of the amount of $\mathrm{Pb}$ in the organic fraction of the filtering material of the dyke. 
Cadmium was accumulated in the labile fractions, due to adsorption and to sorption on the $\mathrm{Mn}$ and $\mathrm{Fe}$ hydroxides. Accumulation of $\mathrm{Cd}$ increased almost two times in the stable fractions of the bottom sediments in the second year of investigation.

\section{Conclusions}

Constructed wetland in Przywidz works as an efficient trap of heavy metals supplied with domestic sewage to the system. Less than $10 \%$ of the $\mathrm{Pb}, \mathrm{Cd}$. and $\mathrm{Cu}$ loads supplied with the inflowing sewage outflows from the system. Just between 5 and $20 \%$ of the retained metals are accumulated in the reed biomass, while the remianing part is sorbed to sediments and construction material of dykes.

\section{References}

1. Forstner V., Witmann. Metal pollution in the aquatic environment. pp. 453. Springer. Berlin, 1981.

2. Obarska-Pempkowiak H., Klimkowska K. Distribution of nutrients and heavy metals between sediments, water and plants in a wetland system in Przywidz, Poland. Journal Chemosphere 39, (2), p.303-312, 1999.

DO1: https://doi.org/10.1016/S0045-6535(99)00111-3

3. Ozimek T., Renman G. The role of emergent macrphytes in the constructed wetlands for wastewater treatment. II Scientific - Technical Conference „Constructed wetlands for wastewater treatment”. Poznan, Poland, 2-3 September 1996: 109-1 18.

4. Vymazal J., Brix H., Cooper P.F., Haberl R., Perfler R. and Laber J. Removal mechanisms and types of constructed wetlands. In: Constructed wetlands for wastewater treatment in Europe (Eds) J. Vymazal, H. Brix, P.F. Cooper, M.B. Green, R. Haberl, Backhuys Publishers, Leiden, The Netherlands, p. 17-66, 1998. 
ECOLOGICAL TECHNOLOGY AND MANAGEMENT

KALMAR, SWEDEN, September 22-24, 1999

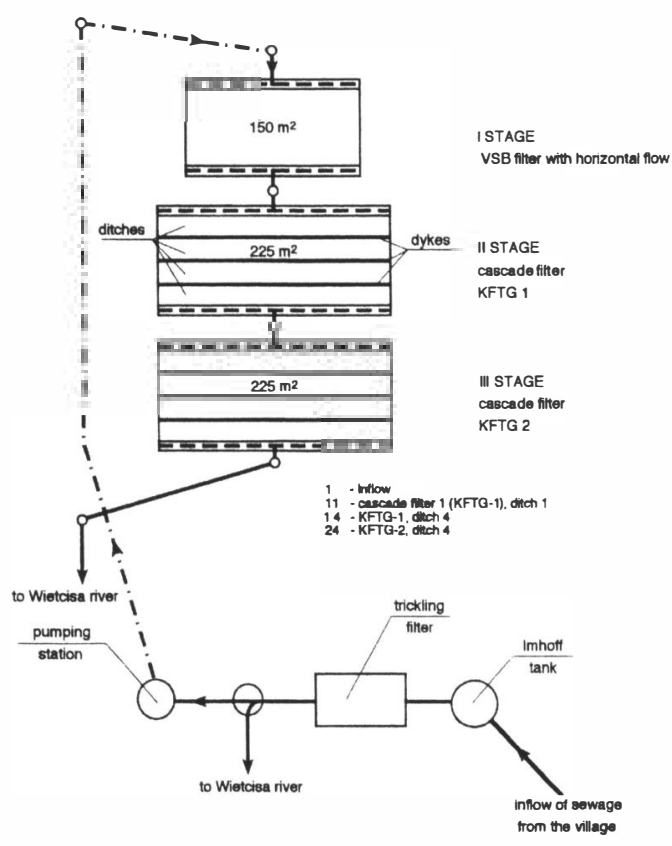

